\title{
正常マウス顎下腺上皮細胞の無血清培養下における株化
}

\author{
薮本正文・岡本哲治・尾崎輝彦・明見能成 \\ 高田和彰

\section{Establishment of normal epithelial cell lines from mouse submandibular gland in serum-free cell culture}

\author{
Masafumi Yabumoto - Tetsuji Окамото • Teruhiko Osaki \\ Yoshinari Myoken $\cdot$ Kazuaki TAKAdA
}

\begin{abstract}
Normal epithelial cell line (M-SG $\alpha$ ) has been established from mouse submandibular gland in serum-free cell culture. Although the mode of chromosome numbers of the cells shifted from diploid to triploid with increasing passage level, the cells had no tumorigenicity in athymic nude mice. M-SG $\alpha$ expressed some of the functional proteins which were characteristic of mouse submandibular gland ductal cells by indirect immunofluorescence antibody technique and also expressed EGF, FGF and TGF $\beta$ receptors. Proliferation of the cells was stimulated by either EGF or acidic-fibroblast growth factor (a-FGF). Furthermore, it was revealed that EGF and FGF were essential factors for the growth. Growth of the cells was inhibited by calf serum or transforming growth factor $\beta(\mathrm{TGF} \beta)$. But the inhibitory activities in calf serum were destroyed by heat treatment. Therefore, it was speculated that some unknown growth inhibitor for epithelial cells which was different from TGF $\beta$ existed in calf serum.

Taken together, this cell line which was established in serum-free culture would be useful to study the growth and differentiation of normal epithelial cells.
\end{abstract}

Key words: Growth and differentiation of epithelial cells (上皮細胞の増殖と分化), epidermal growth factor (上皮成長因子), fibroblast growth factor（線維芽細胞成長因子）

緒

言

正常細胞から悪性細胞への形質転換の過程に, growth factor あるいはその受容体の異常発現が関与しているこ とがあきらかにされつつある1 これ これらをin vitro で解 明するためには，悪性細胞はもとより，てれの由来する 正常細胞の培差系を確立することが必要である。一方, 人の癌腫の $92 \%$ 上皮性の腫瘍である゙ことから, 正常 上皮細胞の培峜は不可欠であると考える。しかし，往 来, 線維芽細胞などの間葉系細胞が正常細胞として研究

広島大学菡学部口腔外科学第 1 檴坐

（主任：高田和彰教授）

Department of Oral and Maxillofacial Surgery I,

Hiroshima University, School of Dentistry (Chief:

Prof. Kazuaki Takada)

受付日：平成元年 9 月 28 日
されてきだ,99.これは, 正常上皮細胞の培堽が非常に 困難であるといらことに起因すると考えられる。 その原 因として培養液中に添加された牛血清中に多く含まれ る, 線維芽細胞の增殖を促進する血小板由来增殖因子 (platelet derived growth factor. PDGF) ${ }^{10,11)}$, あるいは transforming growth factor $\beta(\mathrm{TGF} \beta)^{12,13)}$ などの上皮 細胞増殖抑制因子が考学られる。

近年, G.H. Sato $5^{14,15)}$ は血清の働きは細胞にとって 重要なホルモンや growth factor などを供給することで あるといら仮説をもとに, 血清の代わりに既知の growth factor やホルモンを合成基礎培地中に加えることによ り, 細胞の增殖のみならずその機能をも維持することも 可能であることをあきらかにし，無血清培筫法を確立し た。さらにTsao ら ${ }^{16)}$ が, 低カルシウム培地を用いて無 血清下で正常上皮細胞の初代培跿を可能とした。

一方, 1962 年, S. Cohen ら ${ }^{17}$ により雄性マウス顎下 腺中に歯牙萌出, 眼臉開㤠促進因子として多量の上皮成 
長因子 (epidermal growth factor, EGF) が存在するこ とが発見されて以未，同組織中に神経成長因子（nerve growth factor, NGF) ${ }^{15)}, \beth ロ=-$ 刺激因子 (colony stimulating factor, CSF $)^{19)}$ ，エリスロポイエチン ${ }^{20)}$ なと の growth factor 活性が存在することが報告されてい る。これらの事実は，唾液腺が従来考元られていた外分 泌器官として以外に内分泌器官としても重要な機能を持 っている可能性を示唆している ${ }^{21,22)}$ 。また，顎下腺中に 存在与るこれら growth factor は擷下腺の発生, 增殖, 分化にとっても重要な役割を担っていると考光られる.

そこて本研究では，無血清下で正常マウス顎下腺上皮 細胞の継代培差可能な単層培盖系の確立を試又た。また 長期継代培程を行い, その增殖能, 分化能, growth factor の要求性について解析を行った。

\section{材 料と方 法}

\section{1. 培養材料}

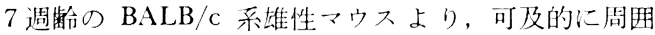
の結合組織を除去した顎下腺を採取して用いた。

\section{2. 培養液}

脱イオン化および逆浸透により純化した水（Milli-Q； Millipore) を用いて, MCDB 15216) あるいは RPMI 1640 と DMEM（以上極東製薬）を $1 ： 1$ に配合した培地 $(\text { RD) })^{23,24}$ に HEPES $25 \mathrm{mM}$ (片川化学), $\mathrm{NaHCO}_{3} 1.2$ $\mathrm{g} / \mathrm{l}$, sodium pyruvate $110 \mathrm{mg} / \mathrm{l}$ (以上和光純薬), kanamycin sulfate $90 \mathrm{mg} / l$, aminobenzylpenicillin $90 \mathrm{mg} / l$ （以上明治製葉）を加え, $\mathrm{pH} 7.4$ に調整し $0.2 \mu \mathrm{m}$ フィ ルター (Acrocap; Gelman Science Inc.)により滤過隇 菌したものを基礎培地として使用した。さらに，crystal一 line bovine insulin $10 \mu \mathrm{g} / \mathrm{ml}$, human transferrin $5 \mu \mathrm{g} /$ $\mathrm{ml}$, 2-amino-ethanol $10 \mu \mathrm{M}, 2$-mercaptoethanol $10 \mu \mathrm{M}$ (以上 Sigma Chemical Co., USA), sodium selenite 10 $\mathrm{nM}$ (半井化学), oleic acid $4 \mu \mathrm{g} / \mathrm{ml}$ (Sigma Chemical Co.) (oleic acid $と$ fatty acid-free bovine serum albumin (Miles Laboratories, Inc, USA) をモル比 $2: 1$ て 結合させたもの（BSA-OL. A と略す），，growth factor として mouse EGF $10 \mathrm{ng} / \mathrm{ml}$ (Receptor Grade, Collaborative Research Inc, USA), fibroblast growth factor (FGF) $1 \mathrm{ng} / \mathrm{m}$ ! を適宜源加した。 FGF は Crabb 5 25) の方法に従い, 牛脳抽出液をへパリンアフィニティーク ロマトグラフィー，それに続いて逆相系高速液体クロマ トグラフィーを用いて䊑製した。培地中のカルンウム濃 度は， MCDB 152 が $0.03 \mathrm{mM}$, RD が $1.12 \mathrm{mM}$ であ った

\section{3. 培養方法}

無菌的に採取した䫇下腺を久スで $1 \mathrm{~mm}^{3}$ 大以下に細 切後, $60 \mathrm{~mm}$ 径プラスチックシャーレ (Falcon, USA) に植え込み，TE-HER 型インキュペーター（平沢製作
所）中， $5 \% \mathrm{CO}_{2}, 37 \mathrm{C}$ の条件下て静置培羕を行った. また，細切した顎下腺をインキュベーター中で $0.05 \%$ トリプンン (Difco laboratories, USA) および0.02\%エ チレンジアミン四酢酸二ナトリウム（EDTA, 片山化学, 大阪）にてゆっくり筧排しながら，30分，60分，90分， 120 分間消化後, トリフンンを $0.2 \%$ トリプンインヒ ビター (Type II -S, Sigma Chemical Co, USA) で中 和遠心後, 初代培差を開始した。

初代培差は, MCDB 152 あるいは RD に insulin, transferrin, 2-aminoethanol, 2-mercaptoethanol, sodium selenite を添加した培地（MCDB5F， RD5F）を基礎培 地とし,さらに $\mathrm{EGF}$ あるいはFGF, あるいは $\mathrm{EGF}$ と FGFを棌加した培差条件で行った。また calf serum (CS) $5 \%$ 源加の条件下でも培差を行った。

\section{4. マウス顎下腺上皮細胞の growth factor 要求性の 検索および M-SG $\boldsymbol{a}$ 細胞株の樹立}

3 の条件で継代培差を行い, 継代 5 代の細胞の growth factor，ホルモンなどの要求性を検索した。 MCDB 152 を基礎培地として 48 well プラスチックプレート（Coster, USA）に5,000 個/well の細胞密度で植え込み, 種 々の条件で 6 日間培教を行い, 生細胞数をCoulter Counter (Coulter Electronics, England) で算出した。 その 結果, MCDB5F に EGF と FGF を添加した条件で最 大の增殖を得た。以後, 同条件で継代培㽰を行い, 正常 マウス頭下腺上皮細胞株 M-SG $\alpha$ を樹立した。

\section{M-SG $\boldsymbol{a}$ 細胞における唾液腺マーカー，上皮マー}

\section{カ一の検索}

24 well プラスチックプレート (Falcon, USA) に植 え込んた 7 代目，48代目の M-SG $\alpha$ 細胞を $1 \%$ パラホル ムアルデヒド（片山化学, 大阪）で30分間固定した後検 索を行った。培笨条件はMCDB5F+EGF+FGFで行っ た。

1 次抗体として, ウサギ由米抗 secretory component (SC), 抗 lactoferrin (LF), 抗 $\mathrm{S}-100$ protein, 抗 myosin, 抗 keratin, 抗 amylase, 抗 vimentin 抗体 (以上 Dako, USA), 抗マウス EGF 抗体 (Collaborative Research Inc）を，対照として正常ウサギ血清を用いた。これら を室温にて 2 時間インキュベート後， 2 次抗体として tetramethyl rhodamine isothiocyanate (RITC) ラベル のヤギ抗ウサギ血清 (Dako, USA) を加之, さらに室温 にて 2 時間インキュベートしたのち, 篮光位相差顕微鏡 (Nikon, DIAPHOT-TMD-EF2A 落射營光装置付倒立 顕微鏡）にて観察を行った。

また，48代目の M-SG $\alpha$ 練胞を MCDB5F+EGF， $\mathrm{MCDB} 5 \mathrm{~F}+\mathrm{FGF}, \mathrm{RD} 5 \mathrm{~F}+\mathrm{EGF}, \mathrm{RD} 5 \mathrm{~F}+\mathrm{FGF}, \mathrm{RD} 5 \mathrm{~F}$ $+\mathrm{EGF}+5 \% \mathrm{CS}, \mathrm{RD} 5 \mathrm{~F}+\mathrm{FGF}+5 \% \mathrm{CS}$ の条件で培養 した。7日後に位相差像にて形態变化の観察, 各種唾液 腺マーカーの検索を行った。 

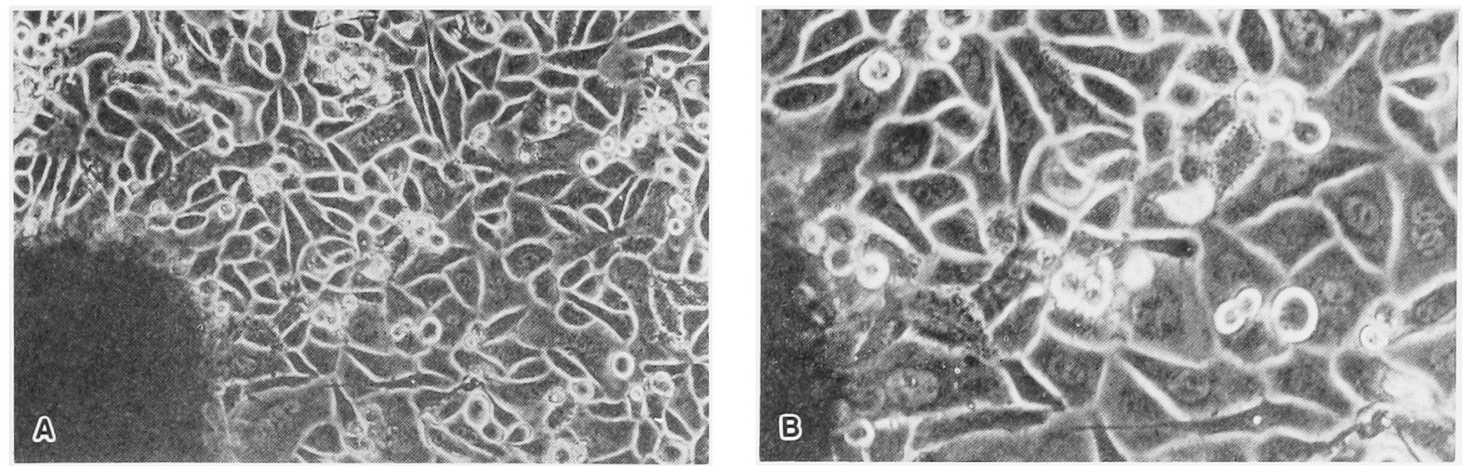

写真 1 初代培養時の M-SG $\alpha$ 細胞の位相差像

$\mathrm{A}$ ：培盖10日目 $(\times 100) \quad \mathrm{B}$ : 培養10日目 $(\times 200)$

\section{6. 染色体数の検索}

秤代 13 代， 49 代の対数増殖期にある細胞を $0.1 \mu \mathrm{g} / \mathrm{m} l$ のディコルシン (Sigma Chemical ('o, USA) 存在下で 8 時間培責した後, EDTAートリプシンにて細胞を分散

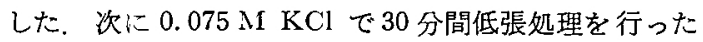
後, カルノア固定液にて固定した．固定後，風乾しギム ザ染色を施し光学顕微鏡観察および写真撮影を行い、染色 体数を算定した。

\section{7. in vivo における M-SG $a$ 細胞の造腫昜性の検索}

Laminar Flow Iso Rack (三基科学工業 K.K.) 内で 飼育中のヌードマウス (BALB/cA-JcI-nu/nu，6 週龄占 日本クレ7 K.K.) の背部皮下に $1 \times 10^{7}$ 個の M-SG $\alpha$ 細 胞（ 9 代执よび25代）を接種した．接種後約 2 か月間観 察し腫瘍形成の有無を肉眼的に判定した。

\section{8. 細胞增殖能の検索および增殖に及ぼす EGF,} acidic FGF, TGF $\beta_{1}$, CS の影響

48 well プラスチックプレートに対数増殖期の細胞を, 5,000個/well の細胞密度で植え込んだ，MCDB5F を基 礎培地として各濃度の EGF, acidic FGF (a-FGF), $\mathrm{TGF} \beta_{1}$ (R \& D, USA), CS を加えて培養を行い， 6 日 後に Coulter Counter にて細胞数を算出した。 TGF $\beta_{1}$ は, EGF $1 \mathrm{nM}$ 存在下ならびに非存在下で検索を行っ た. CS は未処理扣よび $56^{\circ} \mathrm{C} ， 30$ 分加熱処理したもの を用いて検索を行った。

さらに，EGF ならびに FGF の最大活性を示す濃度 を用いて MCDB5F+EGF, MCDB5F+FGF, MCDB5F $+\mathrm{EGF}+\mathrm{FGF}$ の条件で細胞増殖能を検索した。

\section{EGF, TGF $\beta_{1}, \mathbf{F G F}$ 受容体の解析}

48 well プラスチックプレートに植え込んだ継代 10 代 の M-SG $\alpha$ 細胞を Dulbecco の $\mathrm{Ca}, \mathrm{Mg}$ 不含 phosphate buffered saline (PBS (一)) で2回洗浄した後, BSA 5 $\mathrm{mg} / \mathrm{ml}$, HEPES $15 \mathrm{mM}$ を含を MCDB 152 緩衝液 (MCDB/HEPES/BSA buffer, pH 7.4) 中に, 一定量の [125I] 標識された上記 growth factor と巽なる濃度の標

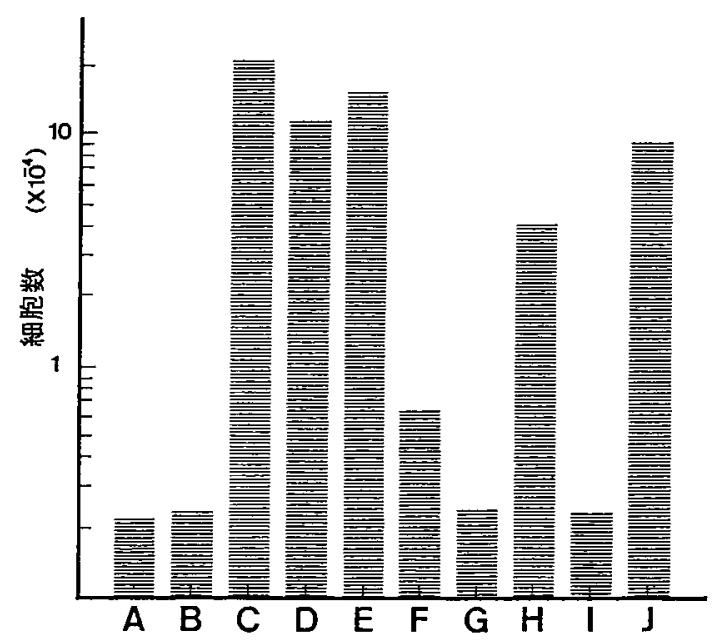

図 1 継代 5 代の M-SG $\alpha$ 細胞の増殖における, $5 \mathrm{~F}, \mathrm{EGF}, \mathrm{FGF}$, oleic acid の要求性

$\mathrm{A}: \mathrm{MCDB}+\mathrm{EGF}+\mathrm{FGF}, \quad \mathrm{B}: \mathrm{MCDB} 5 \mathrm{~F}, \mathrm{C}$ $\mathrm{MCDB} 5 \mathrm{~F}+\mathrm{EGF}+\mathrm{FGF}, \quad \mathrm{D} \cdot \mathrm{MCDB} 5 \mathrm{~F}+\mathrm{EGF}$, $\mathrm{E}: \mathrm{MCDB} 5 \mathrm{~F}+\mathrm{FGF}, \quad \mathrm{F}: \mathrm{MCDB}+$ Insulin (INS) +EGF+FGF, G: MCDB+Transferrin (TRANS) $+\mathrm{EGF}+\mathrm{FGF}, \mathrm{H}: \mathrm{MCDB}+\mathrm{INS}+\mathrm{TRANS}+\mathrm{EGF}$ +FGF, I : MCDB5F+EGF+FGF-INSTRANS, J : MCDB5F+EGF+FGF+BSA. OL.A $\mathrm{A} \sim \mathrm{J}$ の培地にて 24 well プレートに 1 well あたり 5,000 個の細胞を植え込み，6日間培盖を行った後， 細胞数を算出した。

識されていない growth factor を加え， $4^{\circ} \mathrm{C} に て 2$ 時間 インキュベートした, MCDB/HEPES/BSA buffer で3 回洗浄後, 練胞を $0.1 \mathrm{~N} \mathrm{NaOH} 150 \mu l$ で溶解しオート ウェルガンマシステム (Aloka, ARC-600) で放射活性を 測定した，得られた結果を Scatchard 解析 ${ }^{26)}$ 乙れぞれ の growth factor の受容体数ならびに親和性を求めた. 

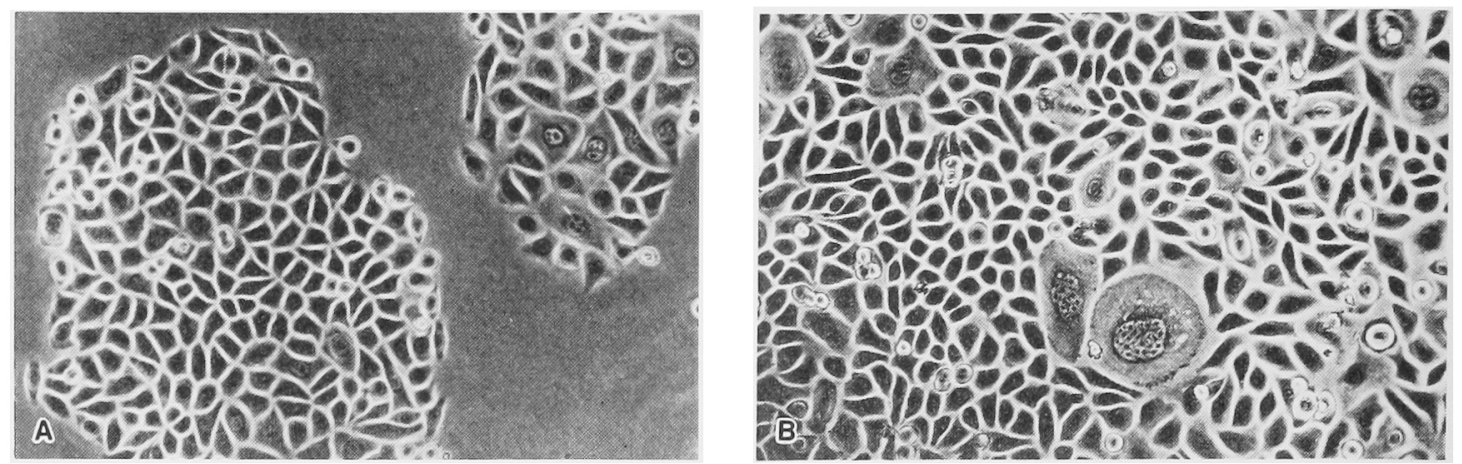

写真 2 継代後の M-SG $\alpha$ 細胞の位相差像 $(\times 100)$

A : 継代 10 代の M-SG $\alpha$ 細胞 B - 継代 71 代の M-SG $\alpha$ 細胞

表 1 継代 7 代扰よび 48 代の M-SG $\alpha$ 細胞 の各種陲液腺マーカー解析

(MCDB5F+EGF+FGFの条件で行った)

\begin{tabular}{l|c|c}
\hline \multicolumn{1}{c|}{ 特異抗原 } & 7 代 & 48 代 \\
\hline SC & + & + \\
LF & + & + \\
S-100 Protein & - & - \\
Myosin & - & - \\
Amylase & + & $+^{*}$ \\
EGF & + & + \\
Keratin & + & + \\
Vimentin & - & - \\
\hline
\end{tabular}

十, 陽性; 土, 抲陽性; 一, 陰性

$1 \%$ パラルムフルデヒド固定後, 螢光抗 体間接法により検索した。

* RD5F+EGF の条件で，Fr. 2 の細胞に 強陽性であった。

結

果

\section{1. 培盖経過}

Explant 法では培着開始 3〜10 日目頃より, EGF あ るいは FGF を添加した培養条件で上皮細胞の遊走がみ られた（写真1），午の後, 原則として 7 日に 1 回継代 培着を行った。 MCDB 152 では, 多角形小型で明瞭な 細胞間隙を有し単層で增殖する細胞群が得られ, 線維芽 細胞の增殖はほとんど認めなかった，RD 培地を用いて も同様な細胞群が得られたが，高カルシウム培地である ため線維芽細胞の增殖を認め大，この傾向は秤代ととる に著明となり，上皮細胞の継代培盖は困難となった，さ らに血清添加培地でも線維芽細胞の過增殖, 上皮細胞の
增殖能の低下により継代困難となった，以上の結果から 上皮細胞の增殖能の最も高い条件は, MCDB5F+EGF +FGF であった.

ま大醉素消化法です，60分，90分消化した群において 初代培養開始翌日より良好な細胞增殖を認め, Explant 法とほぼ同様な結果が得られた。

\section{2. マウス頡下腺上皮細胞の growth factor 要求性} の検索および M-SG $a$ 株の樹立

継代 5 代の M-SG 細胞の増殖における 5 F，EGF， FGF, oleic acidの要求性を検索した結果, 增殖のため に insulin 存在下で EGF あるい性 FGF を必須因子と していた. EGF, FGF の非存在下では増殖を認めなか った. さらに transferrin, 2-aminoethanol 2-mercaptoethanol, sodium selenite 添加により増殖は相加的に促進 され，MCDB5F+EGF+FGF で最大の增殖が得られ た。しかし，oleic acid は增殖に著明な影響を示さなか った(図1).

以上の結果から，MCDB5F+EGF+FGF で継代を重 ね，細胞株 M-SG $\alpha$ を得た。 M-SG $\alpha$ は平成元年 11 月 25 日現在で継代88代目, 細胞集団倍加数 (population doubling level, PDI) 530 で初代培養より約 26 か月経過し ている．継代10代，71代の M-SG $\alpha$ 細胞を位相差顕微鏡 にて観察した（写真 2)．形態的には両者とも多角形小 型の細胞群 (Fr. 1) と，ほとんど增殖能を持たない巨大 な紐胞 (Fr. 2)で構成され，継代が進行しても变化しな かった.

3. M-SG $a$ 細胞における唾液腺マーカーの検索

$\mathrm{M}-\mathrm{SG} \alpha$ 細胞は 7 代, 48代いずれの継代数に执いても， 多角形小型の細胞飞特異的に SC, LF, amylase, keratin が陽性, S-100 protein, myosin, vimentin は陰性であ りほほとどの細胞にマウス EGF が陽性であった（表 $1)$.

さらに，RD 培地では Fr. 2 の細胞に特異的に amylase 強陽性所見が得られた。 

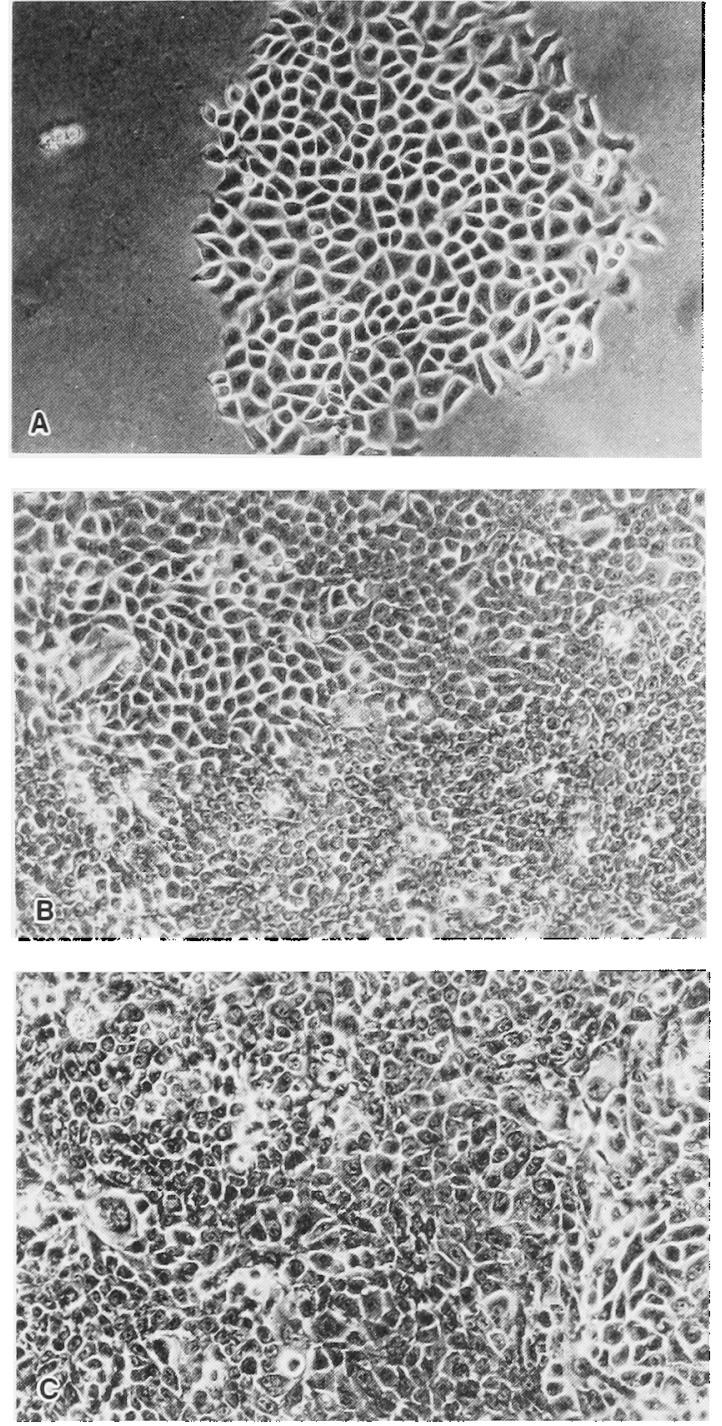
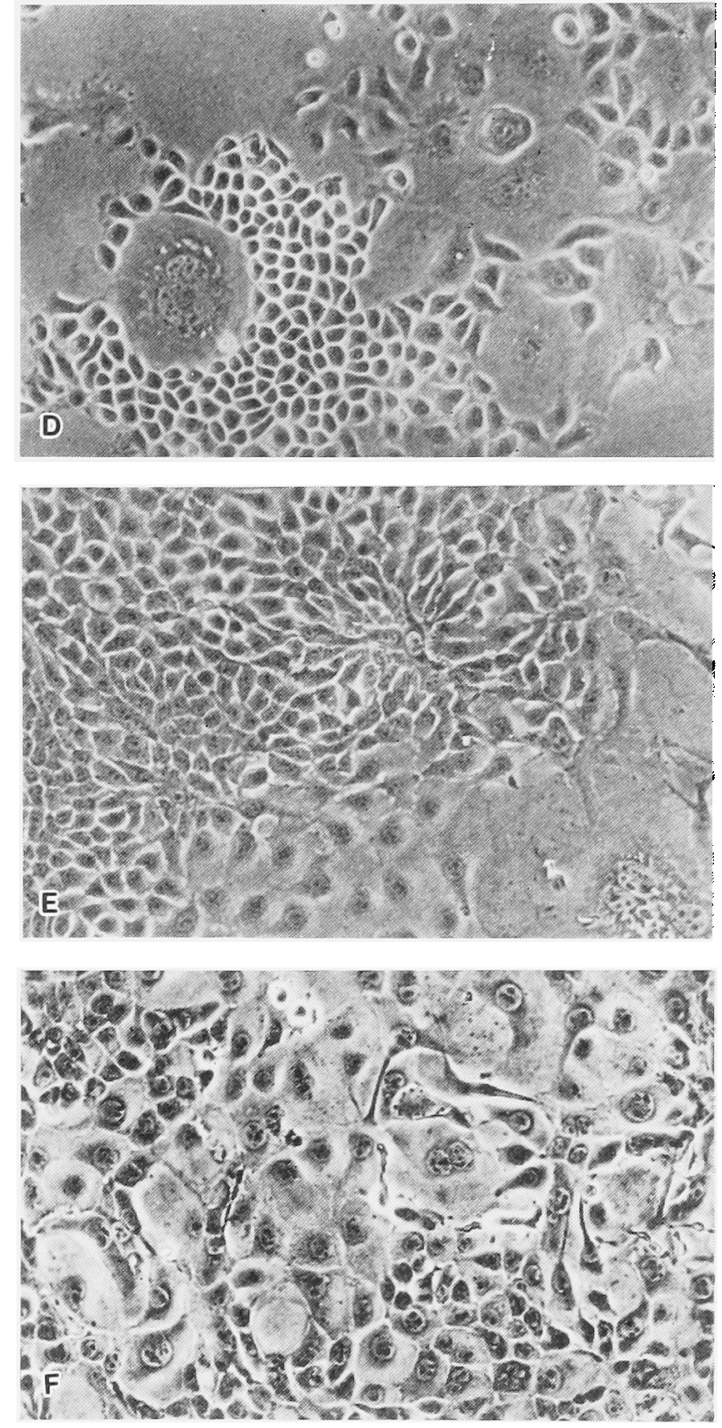

写真 3 継代 48 代の M-SG $\alpha$ 細胞の位相差像 $(\times 100)$

$\mathrm{MCDB5F}+\mathrm{EGF}+\mathrm{FGF}$ で培養した M-SG $\alpha$ 細胞を，以下A）～F）の培地に変更して培荃を行い， 6 日後に位相差像を峴察した。
$\mathrm{A}: \mathrm{MCDB} 5 \mathrm{~F}+\mathrm{FGF}$
$\mathrm{B}: \mathrm{RD} 5 \mathrm{~F}+\mathrm{FGF}$
$\mathrm{C}: \mathrm{RD} 5 \mathrm{~F}+\mathrm{FGF}+5 \% \mathrm{CS}$
$\mathrm{D}: \mathrm{MCDB} 5 \mathrm{~F}+\mathrm{EGF}$
$\mathrm{E}: \mathrm{RD} 5 \mathrm{~F}+\mathrm{EGF}$
$\mathrm{F}: \mathrm{RD} 5 \mathrm{~F}+\mathrm{EGF}+5 \% \mathrm{CS}$

4. M-SG $\alpha$ の細胞形態におよばすカルシウム濃度, 血清の影響

$\mathrm{MCDB} 5 \mathrm{~F}+\mathrm{EGF}+\mathrm{FGF}$ で培屋した $\mathrm{M}-\mathrm{SG} \alpha$ 細胞と比 較して，MCDB5F+EGF で培屋した細胞は全細胞にお けるFr. 2 の割合が增加した。 しかし，MCDB5F+FGF で培盖した細胞はほとんと Fr. 1 のほぼ均一な細胞群 であったまた RD5F+EGF+FGF， RD5F+EGF， $\mathrm{RD} 5 \mathrm{~F}+\mathrm{FGF}$ で培養した細胞の Fr. 1 の細胞は細胞質が
縮小乙 packing され細胞間陌は不明瞭となり, confluent になると重增化する傾向がみられ，扁平上皮細胞に近い 性格を有していると考えられた，Fr.2の細胞はより細 胞質が膨大寸る傾向がみられた。 また $5 \% \mathrm{CS}$ 存在下で は，Fr. 2 の細胞群の膨大化が著明であった（写真了）。

\section{5. 染色体数検索}

$\mathrm{M}-\mathrm{SG} \alpha$ 細胞の染色体数の分布は，13代では約 70〜80 \%の細胞が40本の 2 倍体にモードを示したが，49代では 

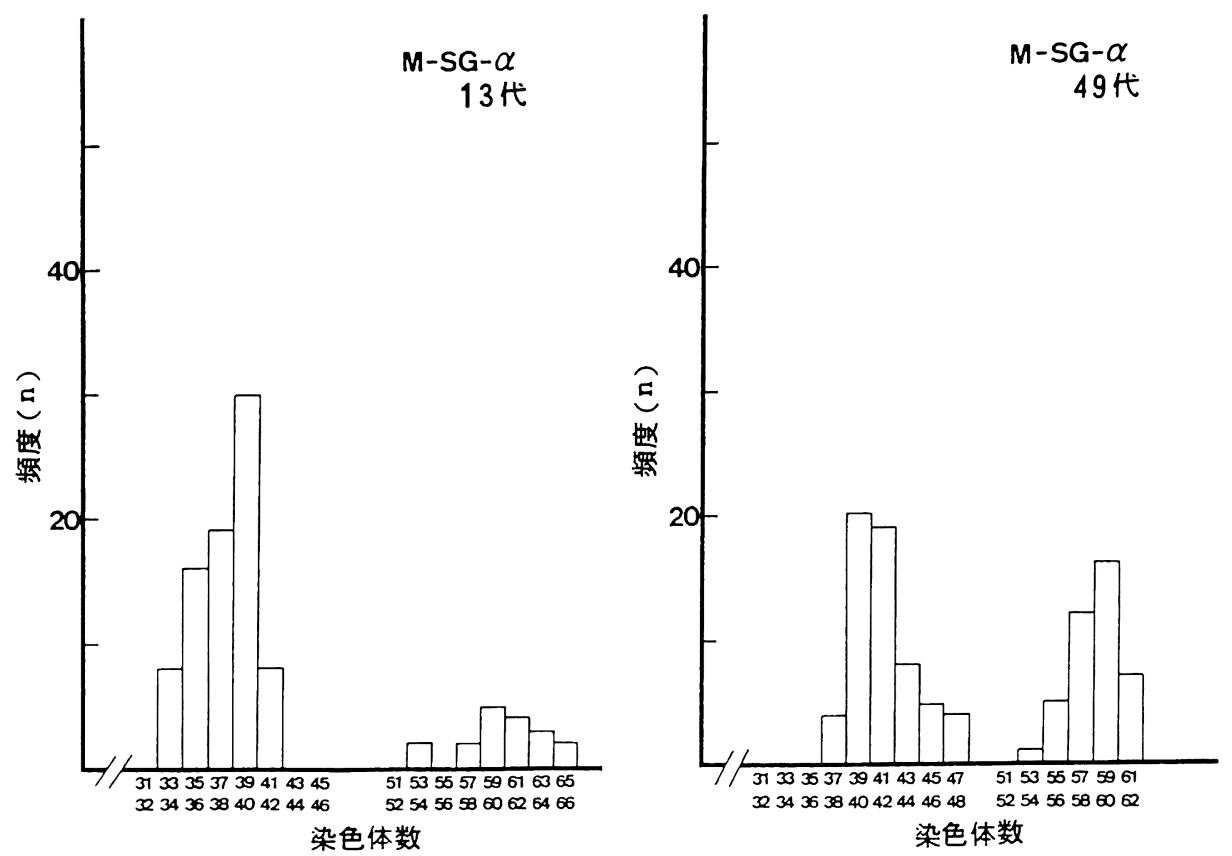

図 $2 \mathrm{M}-\mathrm{SG} \alpha$ 細胞の染色体数分析

約55\%が 2 倍体にモードを示し, 約 $40 \%$ が 3 倍体にモー ドを示した（図2）.

6. in vivo における M-SG $\boldsymbol{a}$ 細胞の造腫瘍性の検索 継代 9 代， 25 代の M-SG $\alpha$ 細胞をヌードマウスに接種 し約 2 か月間钼察した。いずれの群においても肉眼的に 腫痬形成は認められず， M-SG $\alpha$ 絊胞は造腫㿑性を持た ないことがあきらかとなった。

\section{7. 細胞増殖能ならびに細胞増殖に及ぼす growth}

\section{factor, 血清の影響}

EGF, a-FGF は濃度依存的に增殖を促進した。継代 数が増加してもその增殖促進濃度は一定であった（図3$\mathbf{a}$, 図3-b)。EGF の最大活性は1 nMで得られ, FGF の最大活性は $100 \mathrm{pM}$ で得られた。ささらに, EGFによ る最大增殖細胞数と FGFによる細胞数は同一であっ た。また TGF $\beta_{1}$ は EGF $1 \mathrm{nM}$ 存在下で濃度依存的に

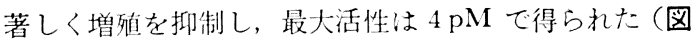
3-c).

CS は継代 7 代，48代の M-SG $\alpha$ 細胞の增殖を濃度依 存的に抑制し，10\%では注ば植え込んだ綀胞数まで抑制 した（図4）。しかし $56^{\circ} \mathrm{C}, 30$ 分熱処理した CS は增殖 抑制活性を贸めなかった。

継代56代の M-SG $\alpha$ 細胞を用いて細胞增殖能を検索し た結果，MCDB5F+EGF，MCDB5F+FGF，MCDB5F $+\mathrm{EGF}+\mathrm{FGF}$ いずれの条件でも細胞倍加時間は25.8時 間であり，增殖率に差を認めなかった（図 5).

\section{EGF, TGF $\beta$, FGF 受容体の解析}

M-SG $\alpha$ 細胞に拈外る EGF, TGF $\beta, F G F$ 受容体解析 の結果, 親和性の異なる 2 種類の $\mathrm{EGF}$ 受容体, 高親和 性の TCF $\beta$ 受容体および FGF 受容体を有しているこ とがあきらかとなった（表 2 ).

考

察

マウス顎下腺上皮細胞の培颀系を確立寸ることは, 正 常上皮細胞の性格および機能の解明のみならず，七ト唾 液腺癌発生機㮖を研究するためにも必要性は高いと考之 られる。しかし，従来より行われてきた血清添加培地を 用いた培盖系では上皮細胞の培荃はきわめて困難であっ た27 30) その理由としては，血清中に存在するPDGF による線維芽細胞の過增殖あるいは TGF $\beta$ などの上皮 細胞に対する增殖抑制因子などが考元られる。

近年，完全合成無血清培地を用いて正常上皮細胞の初 代培墔を行った報告がみられる。しかし長期継代培差に 成功した例はほとんどなく，唯一 Kaighn $5^{31)}$ の報告を みるのみである。彼らは初代より無血清培地を用いてマ ウス表皮角化細胞の長期継代培盖を行った。唾液腺上皮 細胞の無血清培羑はY ang 5 ${ }^{32)}$ が上皮細胞のみを分離し て培荃を試み、コラーゲンゲル内に包埋した状態で約 1 か月間その增殖能，分化能を維持することが可能であっ たと報告している。しかし，現在までわれわれの報告以 


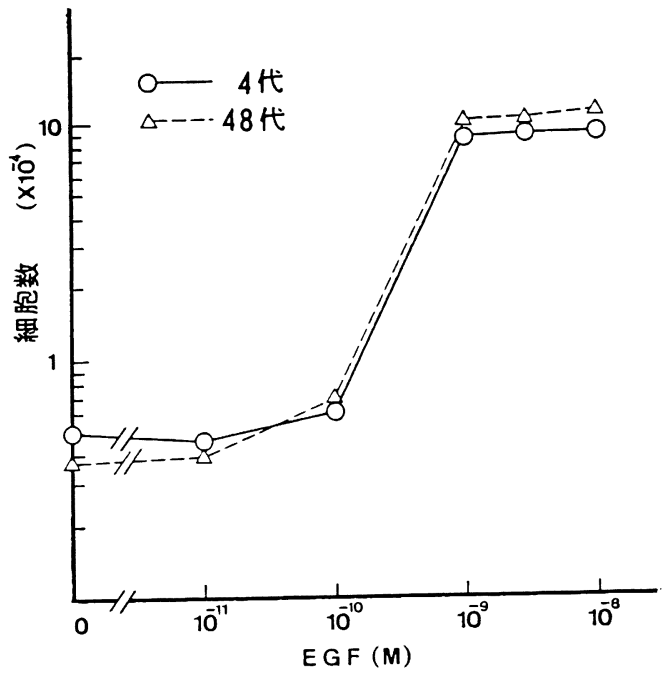

図 3-a M-SG $\alpha$ 科胞の增殖に及ぼす $\mathrm{EGF}$ の影艟

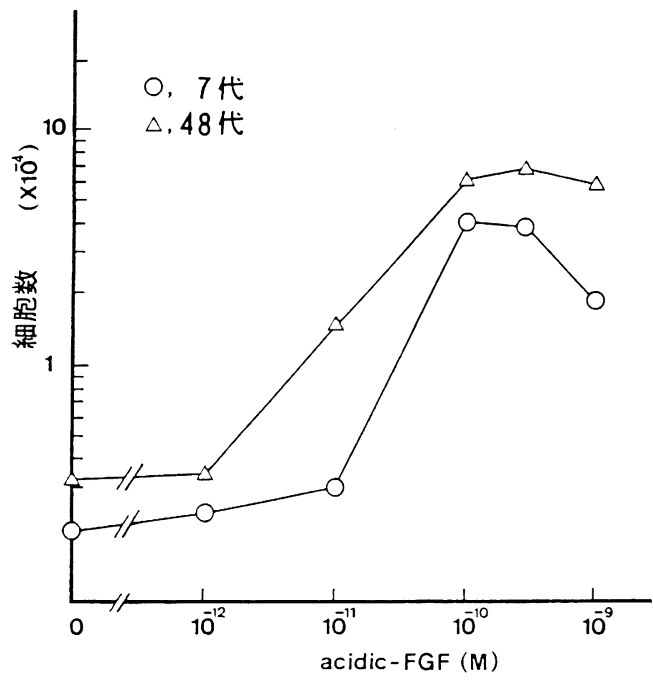

図 3-b M-SG $\alpha$ 細胞の增殖に及活す acidic-FGF の影響

継代 7 代打よび 48 代の M-SG $\alpha$ 細胞に対して検索し た

外に単層培着で唾液腺上皮細胞を長期継代培差した報告 はない

顎下腺には種々の growth factor が存在し，さまざま な細胞の增殖，分化に影篦を与えていることが知られて いる。特に EGF は, 1962年にCohen ら ${ }^{17) に よ り マ ウ ~}$ スの眼瞼開裂および㐪牙萌出促進因子として発見されて 以来最もよく研究されており, Rall $5^{33)}$ は, 他の缄器と 比較して，雄マウス顎下腺中に EGF 前駆体の mRNA レベルが非常に高いことを見い出している。ささらに，最

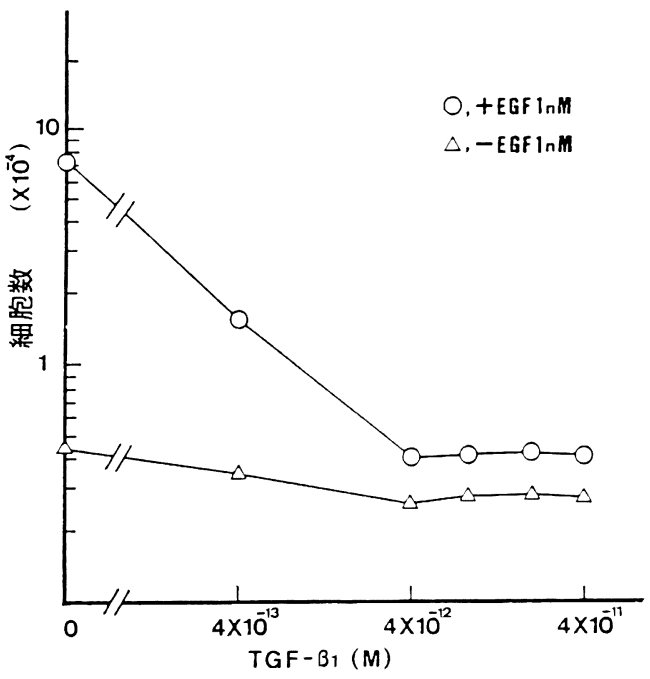

図 3-c M-SG $\alpha$ 細胞の增殖に及活子TGF- $\beta_{1}$ の影 響

継代 48 代の M-SG $\alpha$ 細胞に対して, EGF $1 \mathrm{nM}$ 存在 下拁よび非存在下で检索した。

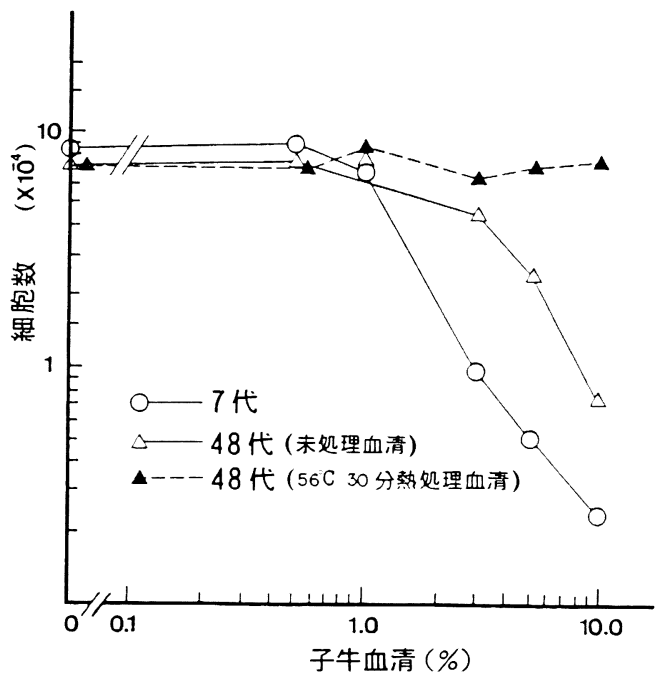

図 $4 \mathrm{M}-\mathrm{SG} \alpha$ 細胞の增殖に及活子子牛血消の影䪪 継代 7 代扣よび48代の M-SG $\alpha$ 細胞に対して検索走 行った。 7 代の細胞には本処理血清の及检索を行 い，48 代の細胞に対しては未処理血消去よび 56 C 30 分熟処理血消について梌索孛行った。

近われわれはマウス罘下腺中に高いFGF 栏因子活性が 存在することをあきらかにした ${ }^{34)}$ FGF は当初 3 T 3 細 胞の增殖促進因子として発見されこのように命名され た 35 37)が，血管内皮細胞增殖因子とまったく同一である ことが明らかとなり ${ }^{38)}$, 最近では表皮角化細胞, 肝細胞 


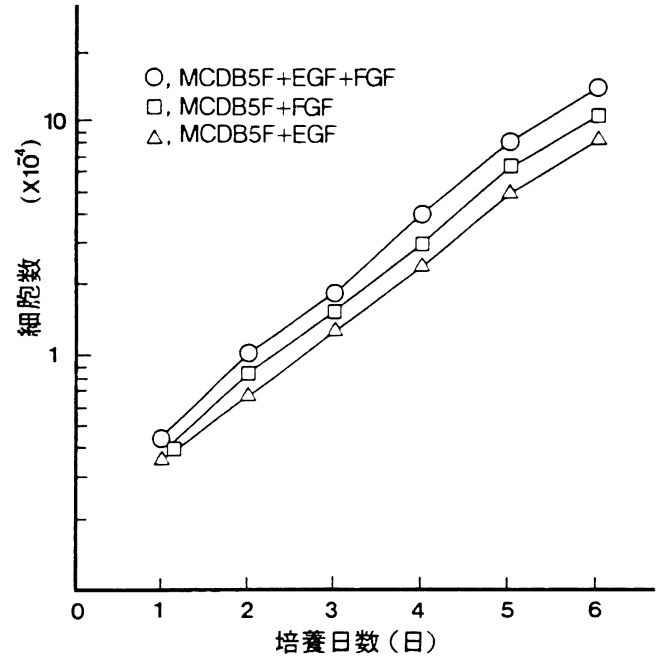

図 5 継代56 代の M-SG $\alpha$ 細胞の增殖曲線

表 2 継代10代の M-SG $\alpha$ 細胞に打ける增殖因子受 容体解析

\begin{tabular}{|c|c|c|c|c|}
\hline & \multicolumn{2}{|c|}{ EGF-R } & \multirow[b]{2}{*}{ FGF-R } & \multirow[b]{2}{*}{$T G F \hat{\gamma}-R$} \\
\hline & $\begin{array}{l}\text { High } \\
\text { Affinity }\end{array}$ & $\begin{array}{l}\text { Low } \\
\text { Affinity }\end{array}$ & & \\
\hline $\begin{array}{c}\text { Receptor } \\
\text { Number } \\
/ \text { Cell }\end{array}$ & $1.1 \times 10^{4}$ & $7.8 \times 10^{4}$ & $1.1 \times 10^{4}$ & $3.3 \times 10^{3}$ \\
\hline $\mathrm{Kd}(\mathrm{M})$ & $9.5 \times 10^{-10}$ & $6.5 \times 10^{-8}$ & $3.0 \times 10^{-10}$ & $1.6 \times 10^{-10}$ \\
\hline
\end{tabular}

*打のおの, scatchard plotにより算出した.

などの上皮采細胞の增殖にも強く関らしていることが報 告されている39 311). in viio で EGF，FGF が買下腺に 多量に存在しているにもかかわらず，顎下腺上皮細胞の 增殖や分化に対してそ机らがどのような役割を果してい るのかこれまで汪とんど解明されていない，そこで無血 清下でマウス罘下腺上皮細胞 (M-SG) の初代培荃を試 み, EGF, FGF か: M-SG 細胞の增殖, 分化に及ぼす影 䅧を梌討した。その結果, EGF 単独でも FGF 単独で も良好な上皮性紐胞の增殖が得られた。最も上皮性細胞 の增殖能の高い培地である $\mathrm{MCDB} 152+5 \mathrm{~F}+\mathrm{EGF}+$ FGF を用いて継代培差を行い，M-SG $\alpha$ 株を樹立した。 このように無血清培地を用いてマウス靧下腺上皮細胞の

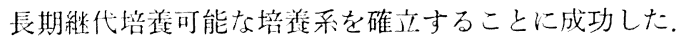

$\mathrm{M}-\mathrm{SG} \alpha$ 細胞はスードマウスにおいて造腫瘍性を持た なかった。またその核型は20代までは70〜80\%が 2 倍休 にモードを示したが，49代では50\%が 2 倍体に，40\%が 3 倍俳沪モードを示した。 Loo ら ${ }^{42)}$ は初代より無血清 下てマウス胎児線維芽細胞の継代培社を行い，PDL 200
でも 2 倍体クロモゾームを維持することに成功し細胞の 老化を認めなかったことを報告している。しかし， Kaighn ら ${ }^{31}$ はマウス表皮角化細胞を無血清下で長期継 代培養した結果, 早期に 2 倍体細胞は消失したことか ら, immortalization の過程に染色体数の增加が必要で あ万らと報告している。今回，M-SG $\alpha$ 細胞でも長期継 代により 3 倍体細胞の增加がみられ，Kaighn らと同様 の結果を得た。

M-SG $\alpha$ 細胞は，形態的に多角型小型の細胞群 (Fr. 1) と多核で細胞質の膨化した細胞およびやや大型の細胞群 (Fr. 2)の 2 種類の細胞群で構成されていた。それらは, 顎下腺の增愐の幹細胞となりらるごく一部の未分化な細 胞群である可能性が考えられる。ささらに, EGF とa-FGF は濃度依存的に M-SG $\alpha$ 細胞の增殖を促進した。また， それぞれの最大增殖促進濃度を用いて MCDB5Fに EGF あるいは FGF あるいは EGF と FGF を添加したいず れの条件でも，M-SG $\alpha$ 細胞は同一の細胞倍加時間を示 したことから， EGF と FGF は M-SG $\alpha$ 細胞の增殖に 対してまったく同じ作用があることが考兄られた。

次に EGF, FGF が M-SG $\alpha$ 細胞の增殖，分化に及ほ す影響を唡討した，位相差顕微鏡による形態学的検索で は，MCDB5F， RD5F を基礎培地として EGF を添加 すると Fr. 2 の細胞の割合が增加した。しかし FGF の みでは汪とんどFr.1の均一な細胞群が得られた。培荃 条件のカルンウム濃度を增加することにより，その細胞 コンポーネントの比率は变化しないが，Fr. 2 の細胞は より細胞質が膨大する傾向がみられた。表皮角化細胞の 分化は低カルシウム培地ては抑制されるが，高カルシウ 么培地ては促進され重層化することが報告されている 44) MCDB 152 のカルシウム濃度は $0.03 \mathrm{mM}$ ， RD は $1.12 \mathrm{mM}$ であり, Fr. 2 の細胞の細胞質の膨化も分化が 促進された結果と考兄られる。

また各種唾液腺マーカー、上皮マーカーの梌索により 增殖能の高いFr. 1 の細胞では, SC，LF, keratin, amylase が陽性，S-100 protein, myosin は陰性であり同 細胞は唾液腺細胞および上皮練胞の性格を持ち、しかも 導管細胞の性質を持っていることが示唆された。さらに ほぼすべての細胞の細胞質にマウス EGF が強陽性であ ったことから，M-SG $\alpha$ 細胞は EGF を産生していると 考兄られた。 in vivo での免疫組織化学的梌索により, 雄 性マウス䫇下腺の顆粒膨大部細胞に EGF が存在するこ

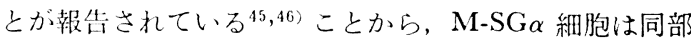
由来である可能性が示咬された，Fr. 1 は低カルシウム 培地では未分化だが，高カルシウム培地で多分化能をも つ增殖性の高い細胞群であることが考えられた。また，

RD 培地中では, EGF 存在下で Fr. 2 の細胞に特異的 に amylase の強陽性所見が得られたことから，高カルシ ウム培地中では EGF により $\mathrm{M}-\mathrm{SG} \alpha$ 細胞の分化が誘導 された可能性が考兄られた。 
このように, EGF は M-SG 細胞の增殖のみならず, その分化に関与していることが示㖫された。 一方 FGF は単独で $\mathrm{M}-\mathrm{SG} \alpha$ 細胞の增殖を著しく促進するが，FGF により増殖する M-SG 細胞は低カルンウム, 高カルシ ウムのいずれの培地においても多角形小型の均一な細胞 群であり，FGF は多分化能をもつと考皇られる未分化 な細胞の増殖のみを促進すると考えられた。

$\mathrm{M}-\mathrm{SG} \alpha$ 細胞の増殖は TGF $\beta$ および CS により濃度依 存的に抑制された。形態的には TGF $\beta$, CSにより辺縁 不規則な細胞質の膨化した細胞の比淬が増加し, 分化傾 向を示している可能性が考光られた。しかし，56 C，30 分間熱処理することにより CS の增殖抑制活性は消失し た，TGF $\beta$ は熱に安定であることから，TGF $\beta$ と異なる CS 中の熱に不安定な未知の因子が上皮細胞の增殖抑制 に関与していると考えられた。従来, 血清添加培地では 上皮細胞の継代培養が非常に困難であったのは, 血清中 にこの上皮細胞增殖抑制因子が存在することによると考 之られた。一方, ヒト扁平上皮癌細胞, 腺癌細胞あるい はマウス扁平上皮癌細胞を用いた無血清培養系では, 血 清によって増殖抑制はみられない（未発表データ）こと から, この因子は正常上皮細胞の癌化に密接に関与して いる可能性が考觉られる。現在までのところ, 同因子は 40\%硫酸アンモニウムで沈踥し, 熱に不安定, 酸に安定 であり，DEAEイオン交换樹脂に吸着する高分子量の 物質であることが明らかとなっている（未発表データ）.

未処理血清中の EGF 濃度は $\left[{ }^{125} \mathrm{I}\right] \mathrm{EGF}$ を用いた radio receptor competition assayにより検索した結果 $1 \mathrm{ng} / \mathrm{ml}$ であった. CS を10\%の濃度で培地中に添加し ても $\mathrm{EGF}$ 濃度は $100 \mathrm{pg} / \mathrm{m} l$ であり, EGF の M-SG $\alpha$ に対する増殖促進濃度と比較してはるかに低いことが明 らかになった。また，血管内皮細胞は培地に $10 \% \mathrm{CS}$ ， $\mathrm{EGF} 10 \mathrm{ng} / \mathrm{ml}$ を添加しても增殖することはできない が，FGF を添加すると增殖できる47ことから，FGF は 血清中にほとんど存在しないと考光られる。これらの事 実からマウス唾液腺上皮細胞を培胥するためには，EGF あるいは FGF を添加し, 培地中から血清を除去するこ とが必要不可欠であることがあきらかとなりわれわれの 用いた無血清培地がきわめて有用であると考えられた。 また，その他の正常上皮細胞も同様の原因により長期継 代培差が困難であったと考兄られる。事実，われわれは 今回用いた無血清培埕系を正常ヒト表皮角化細胞, ヒト 口腔粘膜上皮細胞, ヒト顎下腺上皮細胞などに応用し， 長期継代培差可能であることを確認し，すでに報告し た ${ }^{48)}$.

$\mathrm{EGF}, \mathrm{FGF}, \mathrm{TGF} \beta$ の受容体解析の結果， 2 種類の異 なる親和性の EGF 受容体 (EGF-R) と単一の高親和性 の FGF，TGF $\beta$ 受容体をそれぞれ有していた，EGF-R は $\mathrm{Kd}=9.5 \times 10^{-10} \mathrm{M}$ の高親和性, $\mathrm{Kd}=6.5 \times 10^{-8} \mathrm{M}$ の低親和性 EGF-R が存在し受容体数は約 80,000 個で
あった。 $\mathrm{EGF}$ の $\mathrm{M}-\mathrm{SG} \alpha$ 細胞に対する最大増殖促進濃 度は高親和性 EGF-R の Kd とほぼ一致していた。FGF 受容体は $\mathrm{Kd}=3.3 \times 10^{-10} \mathrm{M}$ で受容体数 10,000 個, $\mathrm{TGF} \beta$ 受容体は $\mathrm{Kd}=1.6 \times 10^{-10} \mathrm{M}$ で受容体数 3,000 個であった。

以上の結果から，M-SG $\alpha$ 細胞株は造腫瘍性を持た ず， in vitro において正常マウス顎下腺上皮細胞の性質 を維持していることがあさらかとなった。ささらに， $\mathrm{EGF}$ および FGF は, positive regulator として, TGF $\beta_{1}$ は negative regulator として M-SG $\alpha$ に働いていることが 示唆された。同細胞は正常上皮細胞の增殖, 分化の研究 に非常に有用性が高く，また血清中の未知の上皮細胞增 殖抑制因子の精製のための標的細胞, さらに新しいヒト

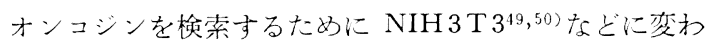
る標的細胞としても非常に有用性が高いと考えられる.

\section{結語}

本研究により，次の結論を得た。

1. 初代より無血清培地を用いることにより, 正常マ ウス䫇下腺由来上皮細胞株 M-SG $\alpha$ を樹立した。同細胞 は平成元年11月25日現在で継代 88 代目，PDL 530 で初 代培差より約 26 力月経過している。継代数が進行しても 細胞倍加時間はほぽ24時間と安定した増殖を示した。

2. 各種唾液腺マーカーの検索により $\mathrm{M}-\mathrm{SG} \alpha$ は導管 細胞の性格を有しており，高カルシウム培地で EGFを 添加することにより大型の細胞に特異的にアミラーゼ陽 性所見が得られた。また大部分の細胞がーウス EGFを 発現しており，in vivoに拈ける顆粒膨大部導管細胞の性 質をもっていることが示唆された。

3. 染色体数は, 培盖初期ではほぼ 2 倍体にモードを 示していたが，継代の進行に伴い2 倍体細胞は約50\%に 減少し 3 倍体細胞の增加を認めた。しかし、 ヌードマウ スにおいて造腫瘍性を認めなかった。

4. M-SG $\alpha$ 細胞には 2 種類の親和性の異なる EGF 受 容体と単一の親和性の高い FGF, TGF $\beta$ 受容体が存在 していた。

5. $\mathrm{EGF}$ あるいはFGF は濃度依存的に著明にM-SG $\alpha$ の増殖を促進し、これらの効果は継代数が増加しても变 化しなかった。 また，哞液腺上皮細胞の增殖のために

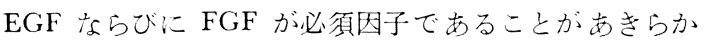
となった。さらに $\mathrm{EGF}$ は增殖と分化, FGF は增殖の みを促進していた。

6. 血清および TGF $\beta$ は濃度依存的に著明に M-SG $\alpha$ の增殖を抑制した。しかし $56^{\circ} \mathrm{C} ， 30$ 分熱処理した血清 の増殖抑制活性は消失したことから, 血清中に TGF $\beta$ と 異なる熱に不安定な未知の上皮細胞增殖抑制因子が存在 することが示唆された。 


\section{引用 文 献}

1) Heldin, C.-H., Westermark, B., et al.: Growth factors: mechanism of action and relation to oncogenes. Cell 37: 9-20 1984.

2) Sporn, M.B. and Todaro, G.J.: Autocrine secretion and malignant transformation of cells. N Engl J Med 303: 878-880 1980.

3) Sporn, M.B. and Roberts, A.B.: Autocrine growth factors and cancers. Nature 313: 7457471985.

4) Todaro, G.J., De Larco, J.E., et al.. Transformation by murine and feline sarcoma viruses specifically blocks binding of epidermal growth factor to cells. Nature 264: 26-31 1976.

5) Hendler, F.J. and Ozanne, B.W.: Human squamous cell lung cancers express increased epidermal growth factor receptor. J Clin Invest.: 647-651 1984.

6) Salomon, D.S., Perroteau, I., et al. Loss of growth responsiveness to epidermal growth factor and enhanced production of alpha-transforming growth factors in ras-transformed mouse mammary epithelial cells. J Cell Physiol 130: 397-409 1987.

7) Cairns, J.: Mutation, selection and natural history of cancer. Nature 225: 197-200 1975.

8) Holley, R.W. and Kierman, J.A.. Contract inhibition of cell division in $3 \mathrm{~T} 3$ cells. Proc Natl Acad Sci USA 60: 300-304 1968.

9) Armelin, H.A.. Pituitary extracts and steroid hormones in the control of $3 \mathrm{~T} 3$ cell growth. Proc Natl Acad Sci USA 70: 2702-2706 1973.

10) Heldin, C.-H., Wasteson, A., et al.: Interaction of platelet-derived growth factor with its fibroblast receptor. J Biol Chem 257: 421642211982.

11) Ross, R., Glomset, J., et al.: A platelet-dependent serum factor that stimulates the proliferation of arterial smooth muscle cells in vitro. Proc Natl Acad Sci USA 71: 1207-1210 1974.

12) De Larco, J.E. and Todaro, G. J.: Growth factors from murine sarcoma virus-transformed cells. Proc Natl Acad Sci USA 75: 4001-4005 1978.

13) Roberts, A.B., Anzano, M.A., et al.: Purification and properties of a type $\beta$ transforming growth factor from bovine kidney. Biochemistry 22: 5692-5698 1983.

14) Barnes, D. and Sato, G. : Serum-free cell culture: a unifying approach. Cell 22: 649-655 1980.

15) Barnes, D. and Sato, G.: Methods for growth of culture cells in serum-free medium. Anal
Biochem 102: 255-270 1980.

16) Tsao, M.C., Walthall, B.J., et al.: Clonal growth of normal human epidermal keratinocytes in a defined medium. J Cell Physiol 110: 219-229 1982.

17) Cohen, S.: Isolation of a mouse submaxillary gland protein accelerating incisor eruption and eyelid opening in the new-born animal. J Biol Chem 237: 1555-1562 1962.

18) Levi-Montalcini, R.: The nerve growth factor 35 years later. Science 237: 1154-1162 1987.

19) Bartocci, A., Pollard, J.W., et al.: Regulation of colony-stimulating factor 1 during pregnancy. J Exp Med 164: 956-961 1986.

20) Clemons, G.K., De Manincor, D., et al.: Immunoreactive erythropoietin studies in hypoxic rats and the role of the salivary glands. Exp Hematol 15: 18-23 1987.

21) Byyny, R.L., Orth, D.N., et al.. Epidermal growth factor: effects of androgen and adrenergic agents. Endocrinology 95: 776-782 1974.

22) Murphy, R.A., Watson, A.Y., et al.: The mouse submandibular gland: an exocrine organ for growth factors. J Histochem Cytochem 28: 890-902 1980.

23) Sato, J.D., Kawamoto, T., et al.: Cholesterol requirement of $\mathrm{P} 3-\mathrm{X} 63-\mathrm{Ag} 8$ and $\mathrm{X} 63-\mathrm{Ag} 8$. 653 mouse myeloma cells for growth in vitro. J Exp Med 165: 1761-1766 1987.

24) Myoken, Y., Okamoto, T., et al.: An alternative method for the isolation of NS-1 hybridomas using cholesterol auxotrophy of $\mathrm{NS}-1$ mouse myeloma cells. In Vitro Cell Dev Biol 25: 477-480 1989.

25) Crabb, J.W., Armes, L.G., et al.. Characterization of multiple forms of prostatropin from bovine brain. Biochem Biophys Res Commun 136: 1155-1161 1986.

26) Scatchard, G.: The attractions of proteins for small molecules and ions. Ann N.Y. Acad Sci 51: 660-672 1949.

27) Marcante, M.L.: On the in vitro behavior of mouse submaxillary gland cells. J Cell Sci 13 : 441-445 1973.

28) Kanamura, S. and Barka, T.. Short term culture of dissociate rat submandibular gland cells. Lab Invest 32: 336-372 1975.

29) Oliver, C.: Isolation and maintenance of differentiated exocrine gland acinar cells in vitro. In Vitro 16: 297-305 1980.

30）井上秀夫, 小西洋太郎, 他：培溇ラット耳下腺 ホルモン応答性に関する研究。㐘基礎誌 24 : 370-378 1982.

31) Kaighn, M.E., Camalier, R.F., et al.: Spon- 
taneous establishment and characterization of mouse keratinocyte cell lines in serum-free medium. In Vitro Cell Dev Biol 24: 845-854 1988.

32) Yang, J., Flynn, D., et al.: Growth in primary culture of mouse submandibular epithelial cells embedded in collagen gels. In Vitro 23: 4354421982.

33) Rall, L.B., Scott, J., et al.: Mouse preproepidermal growth factor synthesis by the kidney and other tissues. Nature 313: 228-231 1985.

34) Okamoto, T., Myoken, Y., et al.: Purification and characterization of heparin binding growth factor from mouse submandibular glands. (in preparation)

35) Gospodarowicz, D.: Localization of a fibroblast growth factor and its effect alone and with hydrocortisone on $3 \mathrm{~T} 3$ cell growth. Nature 249: 123-127 1974.

36) Gospodarowicz, D.: Purification of a fibroblast growth factor from bovine pituitary. J Biol Chem 250: 2515-2520 1975.

37) Gospodarowicz, D.: Purification of the fibroblast growth factor activity from bovine brain. J Biol Chem 253: 3736-3743 1978.

38) Maciag, T., Hoover, G.A., et al.: High and low molecular weight forms of endothelial cell growth factor. J Biol Chem 257: 5333-5336 1982.

39) Maciag, T., Nemore, R.E., et al. An endocrine approach to the control of epidermal growth: serum-free cultivation of human keratinocyte. Science 211: 1452-1454 1981.

40) Halaban, R., Langdon, R., et al.: Basic fibroblast growth factor from human keratinocytes is a natural mitogen for melanocytes. J Cell Biol 107: 1611-1619 1988.

41) O'Keefe, E.J., Chiu, M.L., et al.: Stimulation of growth of keratinocytes by basic fibroblast growth factor. J Invest Dermatol 90: 767-769 1988.

42) Loo, D.T., Fuquay, J.I., et al.: Extended culture of mouse embryo cells without senescence: Inhibition by serum. Science 236: 200-202 1987.

43) Hennings, H., Michael, D., et al.: Calcium regulation of growth and differentiation of mouse epidermal cells in culture. Cell 19: 245-254 1980.

44) McGrath, C.H. and Soule, H.D.: Calcium regulation of normal human mammary epithelial cell growth in culture. In Vitro 20: 6526621984.

45) Gresik, E.W. and Barka, T.: Immunocytochemical localization of epidermal growth factor in mouse submandibular gland. J Histochem Cytochem. 25: 1027-1035 1977.

46) Gresik, E.W.: Postnatal developmental changes in submandibular glands of rat and mice. J Histochem Cytochem 28: 860-870 1980.

47) Hoshi, H. and Mckeehan, W.L.. Isolation growth requirements, cloning, prostacyclin production and life-span of human adult endotherial cells in low serum culture medium. In Vitro Cell Dev Biol. 22: 51-56 1986.

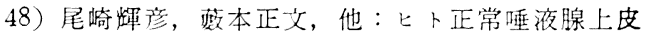
細胞の無血清培滛（抄），日口外誌 $34: 2793$ 1988.

49) Owen, R.D. and Ostrowski, M.C.: Rapid and selective alterations in the expression of cellular genes accompany conditional transcription of Ha-v-ras in NIH3 T 3 cells. Mol Cell Biol 7: 2512-2520 1987.

50) Egan, S.E., McClarty, G.A., et al.: Expression of H-ras correlates with metastatic potential: evidence for direct regulation of the metastatic phenotype in $10 \mathrm{~T} 1 / 2$ and NIH3T3 cells. Mol Cell Biol 7: 830-837 1987. 